\author{
ЛАБОРАТОРНІ ДОСЛІДЖЕННЯ ЯК ЗАСІБ РЕАЛІЗАЦІЇ \\ ПРЕДМЕТНИХ КОМПЕТЕНТНОСТЕЙ ПІД ЧАС ВИВЧЕННЯ ТЕМИ \\ «РОСЛИНИ» ІЗ КУРСУ НАВЧАЛЬНОЇ ДИСЦИПЛІНИ «БІОЛОГІЯ» \\ У 6 КЛАСІ ЗАГАЛЬНООСВІТНІХ НАВЧАЛЬНИХ ЗАКЛАДІВ
}

\title{
LABORATORY RESEARCH AS MEANS OF SUBJECT COMPETENCIES IMPLEMENTATION WHILE STUDYING TOPIC "PLANTS" EDUCATIONAL SUBJECT "BIOLOGY" 6TH GRADE, GENERAL EDUCATIONAL INSTITUTIONS
}

УДК 371.321.1:57

DOI https://doi.org/10.32843/2663$6085 / 2021 / 41 / 2.1$

\section{Москаленко М.П.,}

канд. біол. наук,

доцент кафедри біології

та методики навчання біології

Сумського державного педагогічного

університету імені А.С. Макаренка

Міронець л.п.,

канд. пед. наук,

доцент каредри біології

та методики навчання біології

Сумського державного педагогічного університету імені А.С. Макаренка

\section{Торяник В.М.,}

канд. біол. наук,

доцент кафедри біології

та методики навчання біології

Сумського державного педагогічного

університету імені А.С. Макаренка
У статті описано підходи до реалізації предметних компетентностей під час проведення лабораторних досліджень із вивчення теми «Рослини» курсу навчальної дисци пліни «Біологія» у 6 класі загальноосвітніх навчальних закладів. У цій роботі здійснено спробу розробити нову логічну побудову вступної бесіди із класом перед лабораторним дослідом, яку може використати вчитель під час відповідного уроку. Описано методи із практичним складником, які доречно використовувати на уроках біологіі у 6 класі.

Мета роботи полягає у вивченні можливостей використання навчального матеріалу лабораторних робіт у 6 класі з метою реалізації компетентнісного потенціалу навчальної дисципліни «Біологія».

Визначено, що під час вступної бесіди вчитель фрормує рух думок учнів від звичайного пригадування фрактів із будови органів рослин до аналізу певних нестандартних проблемних ситуацій біологічного змісту для забезпечення розумової активності i реалізації відповідних предметних компетентностей. Обгрунтовано застосування групового методу на уроках із практичним складником під час вивчення біології у старших класах. Зафріксовано, що проведення лабораторних досліджень має забезпечувати виявлення зв'язку будови і фрункції у рослині на рівні тканин та органів для реалізації предметної компетентністі із переліку основних у природничих науках технологіях, зокрема вміння пояснювати явища живої природи. Під час лабораторного дослідження «Будова кореня» учні навчаються розрізняти клітини із різних зон кореня, що забезпечує реалізацію такої предметної компетентності, як уміння розпізнавати клітини, тканини та органи рослин. Обговорення із класом видозмін пагону має закінчитися визначенням морфологічних $і$ фрізіологічних рис, які доводять, що чей орган $є$ дійсно пагоном, а не коренем, зважаючи на розташування у грунті.

Ключові слова: біологія, метод навчання, компетентнісний підхід, лабораторне дослі-
Әження, результати навчання, вступна бесіда, видозміни пагону, будова кореня.

This article describes the approaches to the subject competencies implementation in the course of the laboratory research while studying the topic "Plants" educational subject "Biology" 6th grade, general educational institutions. In the paper, an attempt to develop a new logical framework for the introductory class discussion, which could be conducted by a teacher, preceding a laboratory experiment, is made. The tutorial methods that are appropriate for 6th-grade biology lessons including some practical elements are described. The purpose of the article is to study the capacity of 6th-grade laboratory research learning material as a means of realizing the competence potential of the "Biology" discipline.

As determined, during an introductory conversation, a teacher tries to redirect the class' way of thoughts from just the recollection of facts concerning the structure of plant organs to the analysis of certain non-standard biology content problems, to ensure mental activity, and to implement the relevant subject competencies.

The teamwork in senior classes during the biology lessons with some practical component is justified as highly appropriate. It is stated that laboratory research should serve for students to learn to identify the connection between plant structure and function at the tissues and organs level and, in this way, to ensure the implementation of the basic subject competence, listed for natural sciences and technologies: the ability to explain phenomena in wildlife.

During the laboratory research "Root structure" students are supposed to learn to distinguish cells of different root areas, which enables the implementation of the following subject competence: the ability to recognize plant cells, tissues, and organs. The discussion in class concerning sprout modifications should end up by listing the morphological and physiological features proving that the organ is a sprout, not a root, despite its location in the soil.

Key words: biology, teaching method, competence approach, laboratory research, learning outcome, introductory conversation, sprout modifications, root structure.
Постановка проблеми у загальному вигляді. Сучасний освітній процес у загальноосвітніх навчальних закладах України відбувається через реалізацію компетентнісного підходу. Його суть остаточно і термінологічно оформлена у Законі України «Про вищу освіту»: «Компетентність - це динамічна комбінація знань, умінь і практичних навичок, способів мислення, професійних, світоглядних і громадянських якостей, морально-етичних цінностей, яка визначає здатність особи успішно здійснювати професійну та подальшу навчальну діяльність і $€$ результатом навчання на певному рівні вищої освіти» [3]. 
Компетентнісний потенціал предмету «Біологія» визначений у навчальних програмах для загальноосвітніх навчальних закладів відповідних класів. Навчальна програма з біології для 6 класу передбачає численні лабораторні дослідження, демонстраційні досліди, різноманітні дослідницькі практикуми та міні-проєкти на вибір учителя [1].

Аналіз останніх досліджень і публікацій. Компетентнісний підхід оформлений у численних роботах педагогічної спільноти останніх років $[2$, с. $8 ; 4$, с. $408 ; 5$, с. $198 ; 6$, с. $222 ; 7$, с. $78 ; 8$, 10, с. $76 ; 11$, с. $58 ; 12,13$, с. 40]. Проте слід відзначити, що більшість із них, хоча і має фундаментальний характер, але лише концептуально визначає сутність нової інновації в освіті.

Реалізація компетентнісного підходу розглядається як засіб орормування певних рис особистості учня. Це різноманітні ціннісні речі стосовно природи і суспільства із певним ставленням до органічного світу, загалом до життя, екологічних проблем тощо. Зрозуміло, що процес формування таких характеристик особистості учня базується на біологічних знаннях, уміннях і навичках. Через це визначено нову роль педагога та учня у навчальному процесі. Праця педагога розглядається як творчий процес за фрормою і змістом. На відміну від попереднього традиційного підходу головним нині $€$ результат навчання, а не його зміст. Відповідно до нового підходу МОН України у 2017 році оновило навчальні програми для закладів загальної середньої освіти.

Виділення невирішених раніше частин загальної проблеми. Зважаючи на вищезазначені дослідження, питання про реалізацію предметних компетентностей під час вивчення конкретних тем навчальної програми предмету «Біологія» для закладів загальної середньої освіти залишається, на нашу думку, не досить дослідженим.

Мета роботи полягає у вивченні можливостей реалізації компетентнісного потенціалу предмету «Біологія» під час проведення лабораторних досліджень із вивчення теми «Рослини» у 6 класі загальноосвітніх навчальних закладів.

Виклад основного матеріалу. Лабораторні дослідження забезпечують пізнавальну діяльність під час вивчення навчального матеріалу з біології та виконуються на уроці різними способами: фронтально, групою або індивідуально, за наданим планом. Під час таких досліджень можуть використовуватися натуральні об'єкти, гербарні зразки, колекції, моделі, муляжі, зображення, постійні мікропрепарати, відеофрільми. Мета цієї діяльності - розвиток в учнів уміння спостерігати, описувати, виділяти істотні ознаки біологічних об'єктів, робити висновки, а також фрормування навичок користування мікроскопом, розв'язування пізнавальних завдань тощо.

У шкільній програмі з біології для 6 класу на вивчення теми «Рослини» відведено 20 годин [1].
Потрібно відразу зазначити, що всі вказані у програмі сім лабораторних робіт мають анатомічний зміст: у всіх цих роботах передбачено вивчення внутрішньої і зовнішньої будови вегетативних або генеративних органів [1].

Ми надамо характеристику деяким лабораторним дослідженням із погляду на реалізацію предметних компетентностей. Виконання лабораторних робіт (самостійно чи у групі) та реєстрацію їхніх результатів учитель визначає під час уроку. На нашу думку, у 6 класі передчасно використовувати груповий метод під час таких уроків. Учні ще не володіють технікою проведення лабораторного досліду, тому на початку вивчення біології важливішим є набуття ними відповідних індивідуальних навичок під час самостійного вивчення об'єкту досліду, обробки і фріксації отриманих результатів. Надалі, у старших класах, після тривалішої соціалізації і збільшення рівня самостійності у набутті знань метод роботи у групі буде лише допомагати реалізації предметної компетентності «уміння організовувати та оцінювати свою навчально-пізнавальну діяльність, зокрема самостійно чи у групі планувати і проводити спостереження та експеримент», визначеної у розділі «Уміння вчитися впродовж життя» [1].

Сам хід лабораторного досліду, встановлення його мети, перелік обладнання тощо - це особливий вид практичної діяльності учнів, який потребує окремого розгляду та аналізу, що неможливо втиснути в межі однієї статті [9]. Тому наше дослідження буде присвячено логіці викладення навчального матеріалу у вступній бесіді із класом перед початком лабораторної роботи.

Лабораторну роботу «Будова кореня» потрібно розвести у часі 3 демонстраційним дослідом, під час якого відбувається демонстрація мікропрепаратів внутрішньої будови кореня, або обрати варіант зі суміщенням вивчення внутрішньої і зовнішньої будови кореня та присвятити цьому виду роботи цілий урок. Можливим $є$ варіант, коли клас поділений на групи, кожна з яких виконує одне дослідження: внутрішньої будови кореня із мікроскопом або зовнішньої будови із проростками пшениці чи квасолі. Під час розгляду постійного препарату внутрішньої будови кореня учні наочно розрізняють клітини різних зон кореня та його тканин. Тому це лабораторне дослідження допомагає здійснити таку предметну компетентність, як уміння розпізнавати клітини, тканини та органи рослин [1].

Учитель під час уроку звертає увагу на зв'язок будови клітин в окремих зонах кореня з тими функціями, які вони виконують у клітині. Тим самим відбувається реалізація такої предметної компетенції, як уміння аналізувати значення живлення для рослин [1], адже кореневі волоски виконують саме фрункцію поглинання води і розчинених мінеральних речовин. 
Хоча за тематикою лабораторні роботи мають анатомо-морфологічний характер, їхнє проведення відкриває великі перспективи виявлення зв'язку будови і фрункції у рослині на рівні тканин та органів. На нашу думку, проведення таких досліджень на уроці має забезпечувати виконання саме цього завдання. Тим самим реалізується така предметна компетентність із переліку основних у природничих науках і технологіях, як уміння пояснювати явища живої природи [1].

Прикладом такого підходу може служити проведення лабораторної роботи «Будова бруньки». Перед її здійсненням доцільно провести бесіду 3 учнями, метою якої $€$ з'ясування внутрішньої будови бруньки різних типів і зв'язок цієї будови із функціями, які бруньки виконують у рослинному організмі.

На початку вступної бесіди вчитель пропонує описати зовнішній вигляд і розташування бруньок, адже це орган рослин, який всі діти раніше бачили. Учні легко описують їхній зовнішній вигляд. Так само легко вони визначають функцію бруньок у рослині: із бруньок виростають нові гілки і стебла. Далі вчитель спрямовує бесіду на нижчий рівень організації рослин: від органів до тканин. Для цього він пропонує дітям передбачити наявність певних тканин, навіть не знаючи внутрішньої будови бруньок: «із бруньок утворюються нові стебла або подовжуються старі. Яку з відомих нам тканин можна знайти під час вивчення внутрішньої будови бруньки?» Учні вже знайомі із тканинами рослин із попередньої лабораторної роботи, тому вони визначають наявність твірної тканини, клітини якої весь час діляться і забезпечують ріст стебла у довжину. Цей момент є важливим, адже до виконання лабораторного дослідження відбувається передбачення внутрішньої будови бруньки. Таке прогнозування, абстраговане від реального предмету, сприяє реалізації однієї із освітніх компетентностей у природничих науках і технологіях, а саме уміння пояснювати явища живої природи, використовуючи наукове мислення [1]. До роз'яснення змісту словосполучення «наукове мислення» ми повернемося згодом.

Надалі відбувається активізація вчителем спостережливості учнів через питання: «Які ще ви знаєте бруньки?». Зовсім просте питання, обговорення якого сприяє реалізації спостережливості і допитливості як однієї із предметних компетентностей «уміння вчитися впродовж життя» [1]. Діти легко справляються 3 цим завданням, описуючи опуклі бруньки, які вони бачили на фрруктових деревах поряд із довгастими. Доцільно познайомити клас із новими термінами: «вегетативні бруньки» та «генеративні бруньки». Це доволі прості іншомовні слова, переклад яких в англомовній транскрипції можна спитати в учнів або навести самому вчителю. Таким чином, уже у 6 класі на уроці біології відбуваються перші спроби «доречно використовувати біологічні поняття і найуживаніші терміни в усних чи письмових текстах, читати і тлумачити біологічну номенклатуру і термінологію іноземною мовою», що також входить до компетентнісного потенціалу предмету «Біологія» [1].

Після з'ясування наявності на рослині двох різних типів бруньок і їхнього фрункціонального призначення доцільно перейти від відмінностей між ними до спільних рис. Учитель пропонує назвати спільні риси цих органів, знову звернувшись до спостережливості і допитливості учнів. Зазвичай учні разом із вчителем пригадують, що бруньки вкриті щільними лусками. I знову відбувається перехід від будови до фрункції через з'ясування ролі, яку виконують луски або смолисті речовини, що їх укривають. Вони захищають від механічних ушкоджень, висихання або низьких температур. Такий висновок легко фрормулюється самими дітьми. У цей момент знову відбувається реалізація такої основної компетентності у природничих науках і технологіях, як уміння пояснювати явища живої природи, використовуючи наукове мислення, адже останнє - це не здатність простої констатації, а навпаки, вміння знаходити причинно-наслідкові зв'язки між окремими біологічними фрактами, явищами тощо. Через простий приклад із лусками на бруньках також відбувається знайомство із ще одним іншомовним терміном - «адаптація». Слід обов'язково надати варіант нового терміну українською мовою - «пристосування» як синонім для кращого розуміння учнями суті явища адаптації. І3 цією метою доцільно також запропонувати учням знайти приклад адаптації серед представників тваринного світу. У такий спосіб буде підкреслено єдність органічного світу, в якому рослини і тварини, незважаючи на великі відмінності, існують у межах спільних біологічних закономірностей.

Під час бесіди із класом, побудованої таким чином, відбувається максимальне використання можливостей навчального матеріалу для реалізації його компетентнісного потенціалу. Лише після цього доцільно приступати власне до лабораторної роботи, яка підтверджує наочно всі висновки, зроблені класом під час вступної бесіди.

Лабораторне дослідження «Видозміни пагона» із вивчення надземних і підземних видозмін пагона здійснюється під час розгляду теми «Різноманітність і видозміни вегетативних органів». Іще раз ми наголошуємо, що ця лабораторна робота фрормально за темою присвячена анатомії і морорології окремого вегетативного органу. Ми пропонуємо, як і у випадку із попереднім лабораторним дослідом, використати його для розгляду зв'язку будови і фрункції у рослині на рівні органів і тканин, що їх складають. Під час роботи відбувається знайомство із різними видозмінами пагону, їхніми фрункціями у рослинному організмі. Але підготовка 
до проведення лабораторної роботи важливіша за неї. Окрім зв'язку будови і функції, навчальний матеріал цієї тематики дозволяє ще раз виявити адаптивну реакцію рослин на умови середовища у вигляді різноманітних видозмін пагона.

Доцільно розпочати бесіду з учнями з очевидних для них речей і запропонувати навести приклад відомих їм варіантів розташування пагонів у просторі. Діти легко згадують стебла: прямі, виткі, сланкі, повзучі тощо. Далі вчитель запрошує пояснити таку велику різноманітність пагонів, адже їхня основна функція - забезпечити оптимальне розташування листків щодо світла. Так учитель фрормує перехід думок учнів від звичайного пригадування до аналізу нестандартної ситуації: функція одна, а пагони різні. Разом із педагогом діти з'ясовують, що в умовах різних місць зростання різні види пагона є пристосуванням, адаптацією до певних умов існування і виживання рослини. Доцільно після цього висновку ознайомити учнів із терміном «біотоп» - це ділянка поверхні Землі із більш-менш однотипними умовами існування (грунтом, мікрокліматом тощо). Таке знайомство буде кроком до реалізації одного із розділів компетентісного потенціалу предмету «Біологія» в 6 класі, такого як «Екологічна грамотність і здорове життя», а саме «ціннісне ставлення до навколишнього середовища як до постійного джерела здоров'я, добробуту та безпеки людини і спільноти» [1].

Від зазначених вище екологічних термінів і їхніх роз'яснень ми повертаємося до власне теми лабораторного досліду. Вчитель пропонує учням назвати відомі їм незвичні утворення на пагоні, які зовні нічим не нагадують звичайне стебло, та отримує відповідь: колючки, вусики, різні потовщення стебла. Це різні морорологічні утворення, існування яких потрібно обґрунтувати 3 погляду на фрункціональну доцільність. Таким чином буде витримана головна ідея підготовки до лабораторного дослідження - пов'язати в уявленні дітей ті чи інші анатомічні або морфологічні утворення рослинного організму із їхніми функціями. Учні називають усі видозміни стебла, хоча зовні вони мало подібні до нього. Чи забезпечують вони виконання головної фрункції пагону? Ні, або частково (вусики). Тоді чим можна пояснити потовщення пагона у багатьох рослин, наприклад, у капусти кольрабі, адже це не сприяє кращому розташуванню листків або захисту рослини? Учні припускають, що такі потовщення - це накопичені запасні речовини, потрібні для росту рослин. Так діти знайомляться з новими фрункціями, які може виконувати пагін і, тим самим, пояснюють явища природи, що $€$ однією з основних компетентностей у природничих науках і технологіях, прописаних у компетентнісному потенціалі навчальної дисципліни «Біологія» для 6 класу [1].
Надалі завдання ускладнюється, адже потрібно познайомити клас із видозмінами пагону, розташованими у грунті. Складність полягає саме у їхньому розташуванні, адже, виходячи із життєвого досвіду, діти пов'язують всі частини рослини, які знаходяться під землею, із поняттям «корінь». Але у цьому моменті також приховані великі можливості для реалізації зазначеної вище основної компетентності: уміння пояснювати явища природи, використовуючи наукове мислення [1]. Суть наукового мислення полягає в ухваленні ретельно обміркованих та незалежних рішень. Для такого обмірковування учням потрібен поштовх у вигляді зіткнення із проблемою або нестандартною ситуацією. Теза «пагони у грунті», проголошена вчителем - це ідеальна нестандартна ситуація, яка стимулює учнів до обмірковування і знаходження відповіді, виходячи із наявних знань про предмет. Роль педагога полягає у дозованому і поступовому наданні біологічних фрактів або навіть натяків, які допоможуть розв'язати проблему.

Учитель констатує те, що пагін має багато різних фрункцій і для їх виконання існують надземні видозміни. Окрім надземних, існують також і підземні видозміни пагона. «Ви знаєте, які незвичні підземні утворення існують у рослин?» Учні згадують цибулину, бульбу, кореневище. Усі названі органи рослини є підземними. Пагін - це надземна частина рослини. Чи можна тоді вважати названі утворення видозмінами пагона, можливо це видозміни кореня? Для відповіді на це питання ми повинні знайти ознаки, які точно вказуватимуть на те, що цибулина, бульба і кореневище - це видозміни пагона, а не кореня. Що ж відрізняє пагін від кореня? Які риси будови можуть указувати на приналежність будь-яких органів рослини до пагона?

Така побудова та логіка питань призводить до того, що учні вказують на суттєві відмінності кореня від пагона: останній має бруньки, листки і здатний до фотосинтезу завдяки зеленому пігменту хлорофрілу. Так учні називають головні фракти із загальних знань та уявлень про рослини, тобто ділять всі свої знання на певні категорії та виділяють ті явища, які, на їхню думку, можуть розв'язати питання. Вчитель допомагає: якщо ми доведемо наявність цих ознак, хоч і видозмінених, у цибулини, бульби та кореневища, ми тим самим доведемо, що всі перелічені морфологічні утворення $€$ видозміненим пагоном. Що нагадує цибулина на поперечному розрізі? Учні здогадуються зазвичай легко, особливо якщо їм надати в цей момент ілюстративний матеріал: велику бруньку. Вчитель підтверджує: так, на розрізі цибулина виглядає як велика брунька. Насправді це укорочений пагін. До потовщення знизу так званого денця кріпляться видозмінені листки у вигляді лусок, товстих запасних і тонких покривних. Як і у справжнього пагона, на центральній вісі розміщені листки, а на верхівці 
денця є верхівкова брунька, яка може розвиватись і рости вгору. Чи доводять усі названі ознаки, що цибулина - видозмінений пагін? Тепер учні впевнено стверджують: так, доводять (а ще із нижньої частини денця ростуть корені, як і із нижнього боку пагона). Це твердження учнів $€$ обміркованим, обґрунтованим і прийнятим із мінімальною допомогою вчителя. Це і $€$ елементом набуття вміння пояснювати явища природи, використовуючи наукове мислення [1].

Наступна підземна видозміна пагону - бульба. Схема побудови спілкування вчителя з учнями аналогічна тій, яка була використана під час розгляду цибулини. Учитель пропонує учням визначити у зовнішній будові бульби риси, що підтверджують її приналежність до пагона, а не до кореня, зважаючи на розташування у грунті. Всі діти бачили вічка у бульби, лише не сприймали їх як бруньки на стеблі. Нагадування, що із вічок ростуть пагони як із звичайних надземних бруньок, «відкриває очі» на справжнє походження і роль вічок у бульби. Далі доцільно продемонструвати звичайний пагін (його верхню ділянку) і запропонувати дітям згадати розташування вічок на бульбі. Діти легко згадують, що на одному боці бульби їх завжди більше, а на протилежному - менше. Порівняння із бруньками на пагоні наочно доводить подібність їхнього розташування (чим ближче до верхівки, тим відстань між бруньками менша). Тим самим учні пересвідчуються, що бульба - це видозмінений надземний пагін.

I, нарешті, не морфологічне, а фрізіологічне явище, яке доводить приналежність бульби до пагона. Вчитель питає: що відбувається з бульбою, якщо вона тривалий час знаходиться на сонячному світлі? Учні згадують, що бульба зеленіє. Позеленіння - це поява на світлі пігменту хлорофрілу. А здатність до утворення хлорофрілу і, отже, фоотосинтезу властива якому органу рослини, якій іiі частині? Це властивість пагона, надземної частини рослини. Підсумкове питання вчителя: виходячи із цієї характеристики, чи можемо ми сказати, що бульба - це видозмінений пагін? Учні: так. Це ще одне обмірковано прийняте учнями твердження біологічного характеру.

Обговорення із класом такої видозміни пагону, як кореневище відбувається у тому ж самому ключі: визначення морфологічних і фрізіологічних рис, які доводять, що цей орган є дійсно пагоном, а не коренем, зважаючи на розташування у грунті.

За темою «Рослини» запропоновано на вибір учителя ще декілька лабораторних робіт із будови квітки, насінини, плода. Всі вони мають значний потенціал щодо реалізації компетентнісного потенціалу предмету «Біологія» у 6 класі загальноосвітніх навчальних закладів.

Висновки. На нашу думку, наведені міркування та логіка побудови навчального матеріалу можуть допомогти вчителям біології реалізувати численні компоненти компетентнісного потенціалу навчальної дисципліни «Біологія» під час підготовки і проведення лабораторних досліджень до теми «Рослини» у 6 класі.

Подальші дослідження можуть лежати у площині пошуку нових шляхів реалізації предметних компетентностей під час застосування практичних робіт, демонстраційних дослідів тощо під час вивчення інших тем шкільної програми з біології для загальноосвітніх навчальних закладів.

\section{БІБЛІОГРАФІЧНИЙ СПИСОК:}

1. Біологія 6-9 класи. Навчальна програма для загальноосвітніх навчальних закладів. URL: https:// mon.gov.ua/ua/osvita/.../navchalni-programi-5-9-klas (дата звернення: 01.11.2021).

2. Бондар С. Компетентність особистості - інтегрований компонент навчальних досягнень учнів. Біологія і хімія в школі. 2003. № 2. С. 8-10.

3. Закон України «Про вищу освіту». URL: http:// zakon5.rada.gov.ua/laws/show/1556-18 (дата звернення: 02.11.2021).

4. Компетентність у навчанні. Компетенції. Енциклопедія освіти / гол. ред. В.Г. Кремінь. Київ: Юрінком Інтер, 2008. С. 408-409.

5. Коршевнюк Т. В. Компетентнісний потенціал підручника біології. Проблеми сучасного підручника. 3б. наук. праць. 2018. Вип. 20. С. 197-203.

6. Матяш Н. Ю. Предметна (біологічна) компетентність: її прояв у результатах загальноосвітньої підготовки учнів основної школи. Анотовані результати науково-дослідної роботи Інституту педагогіки НАПН України за 2016 рік. 2016. С. 222-223.

7. Міронець Л. П. Система інформаційних технологій у фрормуванні професійної компетенції вчителя біології. Проблеми підготовки фрахівців : матеріали Міжнар. наук.-практ. конф. Т. 25. Дніпропетровськ: Наука і освіта, 2005. С. 78-79.

8. МОН. Життєві компетентності на основі якісних знань, замість вимог - очікувані результати навчання, більше довіри до вчителя. URL: https://mon.gov.ua/ ua/news/usi-novivni-novini-2017-06-19-mon-onoviloprogrami-5-9-klasiv (дата звернення: 02.11.2021).

9. Педагогіка. Лабораторний практикум з ботаніки як засіб розвитку самостійності учнів. URL : http:// 8ref.com/19/referat_193903.html/ (дата звернення: 30.10.2021)

10. Рибалко Л. М. Компетентнісно орієнтоване навчання як стратегія інноваційного розвитку освіти в Україні. Інноваційний розвиток вищої освіти: глобальний та національний виміри змін : матеріали Міжнар. наук.-практ. конф. Суми. 2017. С. 76-79.

11. Степанюк А. В. Фундаменталізація змісту біологічної освіти школярів. Педагогічний альманах. 2010. Вип. 5. С. 58-63.

12. Хуторской А. Ключові освітні компетентності. URL : http://osvita.ua/school/theory/2340/ (дата звернення: 30.10.2021).

13. Шапран Ю. П. Теоретичні та методичні засади формування профресійної компетентності майбутніх вчителів біології : автореф. дис. ... д-ра пед. Наук. Київ. 2014. 40 c. 